Volume 4 Number 4 June 2021

\title{
Leadership Skills at Islamic Educational Institutions
}

\author{
Aswaruddin ${ }^{1}$, Novita Sari ${ }^{2}$ \\ ${ }^{1}$ MIN 11 Kota Medan \\ ${ }^{2}$ STAIJM Tanjung Pura Langkat \\ aswaruddin1973@gmail.com,novitasarinovi9988@gmail.com
}

\begin{tabular}{ll}
\hline Article History & Received : Feb $9^{\text {th }} 2021$ \\
& Revision : April $13^{\text {th }} 2021$ \\
& Publication : June $30^{\text {th }} 2021$ \\
\hline
\end{tabular}

\begin{abstract}
The purpose of this research is to discuss leadership skills in mi, MTs and MA educational institutions, this research method is a library review, the results of this study is the ability of Madrasah leadership through technical, conceptual and social skills in implementing Madrasah-based Management. The indicators are: 1) Technical Skills (Technical Skills) indicators are the ability to apply technical procedures and use special skills in carrying out certain tasks, as well as the ability to empower teachers, 2) Human Skills (Human Skills) indicators are the ability to cooperate, able to establish harmonious relationships with the community, able to apply leadership principles in accordance with the maturity level of teachers and other employees in madrasah, able to work with the management team. Conceptual Skills indicators are the ability to think analytically and solve problems in an integrated manner, the ability to realize the objectives of madrasah. .
\end{abstract}

Keywords: Leadership, Islamic educational institution, Madrasah Based Management

\section{INTRODUCTION}

Human beings are social beings who can not live alone, in everyday life everyone definitely needs the help of others, therefore humans belong to group creatures, group life definitely needs someone who is able to lead his group so that goals in life can be achieved easily. A person who is chosen as a leader is usually someone who has a higher knowledge and passion because the leader is expected to lead his members towards change and success.

But actually everyone is born as a leader, everyone has the ability to lead either leading himself or leading a large group or organization, leadership becomes one of the natural abilities that everyone has.

One's most basic leadership ability is to lead oneself, everyone must have experience of leading oneself in daily life, such as leading himself to have positive activities and always be a better person every day. If man does not have a 
leadership spirit in his life, his life will not be directed like he has no purpose and dreams.

Leadership is a fundamental element in dealing with one's style and behavior. It is a potential to be able to make others (led) follow what the leader wants into reality. It involves an element of emotion that can in fact always change. Implementing leadership doesn't always go smoothly. It may be that the employee led by the manager is hesitant about the manager's ability, it is not clear what and why the manager instructed something, apathy towards the manager or could even indicate a conflict with the manager. Good employees make it as self-motivation for self-development in the present and future.

The concept of leadership is basically derived from the word "lead" which means guided or guiding. From the word "lead" gives birth to the word working "Leadering" which means to guide or guide and the noun "leader" which is the person who serves to lead, or the person who guides or leads. While leadership is one's ability to influence others in achieving goals. Davis in Harbani Pasolong, (2013:1) also mentions that leadership is the ability to influence or persuade others to achieve goals enthusiastically.

Hadari Nawawi, (2012:56) Leadership is a process or series of activities that are interconnected with each other, although they do not follow a systematic series. The series contains activities to move, guide and direct and supervise others in making things, both individually and together. All of these activities can be referred to as attempts to influence the feelings, thoughts, and behaviors of others towards achieving a goal. Therefore leadership is also a process of interaction between a leader and a group of others, which causes people or groups to do something that is in accordance with the will of the leader. Leadership includes attention to common goals.

Defining the meaning of leadership as a skill in exerting influence on an individual or group of people to obtain a vision or purpose. As with formal organizations, this impact can be formal given by the leadership who holds a position in the organization so that it must be adhered to and implemented by its subordinates. A leader in view of how the leader can influence others with his charisma and can also control all the situations and conditions he is facing in his environment. A leader must also have emotional stability in leading the members under him and be fair to the members.

Leaders direct their energy to individuals trying to achieve something together. In general, we mean that leaders and followers have a common purpose. Attention to common goals gives leadership an additional ethical tone, as it emphasizes the need for leaders to work with followers to achieve specific goals. The emphasis on mutuality reduces the likelihood that leaders take action against 
their followers in unethical or coercive ways. It also increases the likeness that leaders and followers will work together for the common good.

From the above opinion, it can be concluded that the role of a leader is very important in improving the performance of staff or subordinates because where the leader is able to provide motivation, encouragement, correct and provide solutions to problems that occur in the organizational institution, to perpetuate this important role, every leader is required to continue to multiply and develop his abilities over time. The following description will review some forms of abilities that a leader should have.

However, the concept of leadership in education cannot be separated from the concept of leadership in general. Formally leadership activities must be organized by a person occupying a certain position or position in which there are a number of people who must work together to achieve one goal.

In primary and secondary education institutions, the so-called top manager is the head of madrasah or madrasah head whose role is to move, influence and encourage all components in madrasah institutions to be able to achieve educational goals in madrasah institutions that they lead. The head of the madrasah as the leader in the madrasah has full authority in advancing and developing the madrasah. The success of madrasah depends on the maximum ability and efforts of the madrasah head in managing madrasah. Therefore, the leadership of the head of madrasah is an important factor in the achievement of madrasah performance.

\section{METHOD}

The data collection method is a library study. The method to be used for this study is the study of literature. The data obtained are collected, analyzed, and concluded so as to get conclusions about the study of literature.

\section{RESULTS AND DISCUSSION}

Indonesia lost many leaders with integrity because nowadays everything is weighed with money. The leaders and rulers of cendrung forget the people who are actually the rightful owners of the Indonesian nation.

Chairman of the National Democratic Board of Trustees Sultan Hamengku Buwono X said that the leaders and rulers of this country should look at what the founders of Indonesia did. According to the Sultan, the people as the largest part of the nation are often forgotten because the leader only thinks for his own faction.

"Our founding fathers built a nation and this Country risked lives selflessly enriching themselves, they donated to the point of exhaustion with their own lives. 
All sincere. They also want to argue with anyone, let their fellow nation's children have different thoughts, unapologetic traditions, and ethnicities. However, once out of the room, they remain in togetherness, can build good communication," said Sultan who was present at the inauguration of the National Democratic administration of Depok, Saturday (28/5).

The contrasting conditions, according to the Sultan, are precisely the case today. There can no longer be found togetherness among leaders with different backgrounds. Sultan said, the leader of the nation today tend think for the sake of his party.

"They argue in siding, in meetings, different views, so out yes quietly, do not build togetherness. If you can, now in power, think for your own sake. Our predecessors put the interests of the people first so that they would be different. If now, it seems that the figures put their own parts ," Said Sultan.

Sultan said it was very difficult to find a leader of integrity and willing to fight for the interests of all people, regardless of background. At that time money governs and determines everything, including the integrity of the leader.

Separately, Chairman of the Constitutional Court Mahfud MD said, the Indonesian nation is currently under great danger because of the corruptive behavior of policy makers. The great danger is because many people actually know the occurrence of corruption, but do not have the courage to express it so it is difficult to prove the law. Mahfud said, what he revealed about the money that the former General Treasurer of the Democratic Party Muhammad Nazaruddin gave to the Secretary General of the Court is only a nail tip of the large stockpile of koruftip phenomenon in this country.

Previously, Coordinator of The Division of Political Corruption of Indonesia Corruption Watch Ade Irawan and Executive Director of ELSAM Indriyani D Saptaningrum assessed a number of pro-democracy intellectuals and activists who belong to political parties are getting lost in the pragmatic political currents. Their idealism should be able to inject positive influence so that the party will rightly become a pillar of democracy, entrench politicians with integrity, and fight for the interests of the people (BIL/IAM).

Tijan (1995:89) found that democratic leadership applied by parents in the family influenced the attitudes and behaviors of children. Due to the influence of parental leadership, the child is formed a firm attitude, able to communicate in society at all levels, willing to respect others, do not like to win alone. The leadership of domokratis parents and the acceptance of guidance in school together turned out to affect the attitude and expectations of asertif behavior in the child. The amount of democratic leadership contribution to child asertive behavior is $5.695 \%$. 
Husaini Usman (1997) found that school leadership specifically in vocational education must have technical expertise, both in the true and shorthand sense. The meaning of TEKNIK is briefly Skilled, Work ethic, Courage, Negotiation, Business Intuition, and Entrepreneurship.

Husaini Usman(2004) found that there is a positive relationship between the nature of leadership, the use of power, the climate of power, the criteria for success, and the commitment of leaders together with the primal leadership of smk heads. The amount of contribution to primal leadership of leadership traits $(2.47 \%)$, the use of power (13.58\%), the climate of school organizations $(21.8 \%)$, the criteria for success (17.19\%), the commitment of leaders $(10.43 \%)$ and simultaneously (63.30\%).

The results of research on successful business leaders conducted by Kotter (1998) found that effective senior leaders are: (1) have a good knowledge with products, technology, markets, and people; (2) have sharp thinking, analytical ability, strategic thinking capacity, and multidimensional; (3) have a goodtrack record; (4) as a key player voicing internal and external relations of the institution; (5) have good interpersonal skills; (6) energetic; have high motivation to lead and confidence.

The results of peters \&austin research (1986) found the main characteristics of leadership quality. They found that what determines quality in an institution is leadership. They also determined that a certain leadership style could lead the institution to a quality revolution. The leadership style is called Management by Walking About (MBWA) style. The desire to improve quality should be strolled down the street and cannot simply be communicated behind the counter. MBWA's style emphasizes the importance of the presence of leaders and the implementation of their staff to inputs, processes, and outputs for quality improvement. This MBWA style attaches importance to communication vision and quality values to internal staff and external customers. Peters \&Austin suggested in his research, namely the importance of qualified leaders (superior) in improving the quality commitment to quality belongs to every leader. Quality improvement requires strong leadership.

In 1998, Management Europa surveyed the top 1500 and middle managers to find out what qualities of leadership they needed. The study found five key attributes of leadership, namely (1) the ability to build effective teams, (2) being able to be good listeners, (3) being able to make decisions, (4) being able to retain the best people, and (5) being able to get along with the best people around them. The quality of leadership required according to the top manager is (1) able to make decisions, (2) strong desires, (3) ambitious, (4) energetic, and (5) motivated by power. 
Robert (1992) in his research found 17 qualities of leadership, namely (1) courageous; (2) a strong desire to lead; (3) emotional stamina is able to withstand disappointment; (4) strong physical stamina; (5) empathy-sensitive to the values, cultures, beliefs, and traditions of others; (6) unequivocally; (7) anticipation; (8) time discipline; (9) competition; (10) confident; (11) accountability outside the self; (12) accountability to the self; (13) trustworthy; (14) hard-hearted; (15) independent; (16) able to serve; (17) faithful.

Different leaders and managers are leaders more focused on people, while managers are more focused on non-human beings. There are opinions, leaders can be managers, but managers can't be leaders. However, some argue otherwise. There are also argues, managers who are increasingly competent over time will become leaders. Will the increasingly incompetent leader become a managerovertime? Leaders and managers are just as important as they are. They function according to their respective roles. Our principal is more strengthened as a manager than as a leader. Of the 33 competencies of the principal in permendiknas 13 year 2007 on the Standard Principal / Mandrasah turned out to be much more the role of manager than the leader.

Future leadership is leadership that has an honest, courageous, visionary, competent, inspiring, empowering fund. Because honestly, he will defend the truth. He'll be brave because he's right. The development of leadership theory can be simplified into five approaches: (1) traits, (2) behavior, (3) situational/contingency leadership, (4) transformational and charismatic leadership.

The leader is a priest in his group of followers. As a priest, he set an example for his followers. As a priest, he had certain advantages over his followers. As a priest when he behave or misbehaves, he is willing to receive constructive rebukes or criticisms from his followers. As a priest, he willingly(legowo)handed over his leadership to the followers

yes if he is no longer capable of being a leader or there is a leader who is better than him.

Future educational leadership, namely learning leadership(instructional leadership), which is leadership that focuses on improving the quality of student learning. Therefore, prospective principals need to be equipped with learning competencies through training or technical guidance (bimtek) of prospective principals. Training or training the principal becomes unfe professionals if they do not provide learning leadership materials because the main customers of the school are students.

\section{CONCLUSION}


Leadership skills based on the concept of ability in showing the meaning of skills or ability. Meanwhile, leadership is the ability of leaders to take action. The work of the leader is very complex and multidimensional, so it requires a variety of skills, because the work will be more effective if the leader has the skills.

The ability of leaders to leverage others through trust and cooperation. This means that a leader is required to have the ability to empower others to be able to perform the actions or work expected by the leader. This can be done by the leader, because he has the power to make the subordinate obey or follow the command of the leader.

Based on previous discussions about leadership capabilities is the ability of Madrasah leadership through technical, conceptual and social skills in implementing Madrasah-based Management. The indicators are: 1) Technical Skills (Technical Skills) indicators are the ability to apply technical procedures and use special skills in carrying out certain tasks, as well as the ability to empower teachers, 2) Human Skills (Human Skills) indicators are the ability to cooperate, able to establish harmonious relationships with the community, able to apply leadership principles in accordance with the maturity level of teachers and other employees in madrasah, able to work with the management team. Conceptual Skills indicators are the ability to think analytically and solve problems in an integrated manner, the ability to realize the objectives of madrasah.

\section{REFERENCES}

A.M. Mangunharjdna, SJ (2004). Kepemimpinan . Yogyakarta: Kanisius Bangun, Wilson. (2008). Intisari Manajemen. Bandung: Refika Altama.

Chaplin,kamus tes psikologi alih bahasa Kartini Kartono. (Jakarta Raja Grafindo Persada 2000)

Drat, Richard. L. (2010). New Era Of Management. South Western : Cengange Learning

Fuad Hasan dkk, (2003)Kamus istilah psikologi, Jakarta. Pusat bahasa Departemen Pendidikan Nasional

Hadari Nawawi dan M. Martini Hadari, (2012) Kepemimpinan Efektif (Yogyakarta: Gadjah Mada University Press

Handoko, Hani. (2000), Manajemen. Yogyakarta. Publishers, Twoth Edition BPEE Harbani Pasolong. (2013) Kepemimpinan Birokrasi, Bandung: Alfabeta J. Winardi, (2004)manajemen perilaku organisasi . Jakarta Kencana Manz, Charles C dan Sims, Jr. Henry P. (2001). The Super Leadership. San Fransisco : Jossey Bass Publishers

Salusu, (1996). Pengambilan Keputusan Stratejik untuk Organisasi Publik dan Organisasi Nonprofit. Jakarta: Gramedia Widiasarana Indonesia 
Stephen P. Robbins, Coulter, Mary. (2007). Manajemen, Edisi Kedelapan, Jakarta : Indeks

Veithzal Rivai dan Arviyan Arifin, (2009) Islamic leadership: Membangun super leadership melalui kecerdasan spiritual . Jakarta: Bumi Aksara

Wahjosimidjo. (2010). Kepemimpinan Kepala Sekolah. Jakarta Grafindo Persadas 